\title{
ON THE BIBLIOGRAPHY OF A LATE EIGHTEENTH-CENTURY GERMAN WORK ON NATURAL HISTORY AND AN EARLY RECORD OF LEUCISCUS MEIDINGERI HECKEL, 1852 (PISCES, CYPRINIDAE) IN THE RIVER SYSTEM OF THE UPPER DANUBE ON 6th APRIL 1786
}

\author{
by \\ S. J. DE GROOT \\ Netherlands Institute for Fishery Investigations, IJmuiden, The Netherlands
}

\begin{abstract}
The bibliography of a hitherto inaccurately described anonymous eighteenth-century popular German work on natural history is given, dealing with mammals, birds, fishes, amphibians and reptiles. As an addendum to this work the publisher has given an engraving of an unknown fish from the river Lech, river system of the Upper Danube. The fish could be identified as the cyprinid Leuciscus meidingeri Heckel, 1852. The observation of the species was made 66 years before its recognition as a new species by Heckel.
\end{abstract}

\section{INTRODUCTION}

In the spring of 1969 , in an antiquarian bookshop, I came across a collection of 28 engraved plates, large oblong folio; copies in miniature of figures of fishes from the works of Ray (Willoughby), Bloch and Sauvigny. In the legend to the plates there was no indication as to the book to which they belonged, only that they formed part of a larger work on natural history, in the German language, which was also said to contain a table of contents in Latin, German, French and English. The publisher, engraver and year of publication were given on the first plate. The publisher is the Gemeinschaftlichen Handlung der kaiserlichen privilegio franziscischen Reichsakademie F.K.V.W. (Freyer Kunste Und Wissenschaften) in Augsburg, the engraver is Friedrich Kirschner and the year of publication is 1786 . However, about six months later the text-volume to the plates turned up in the same bookshop. This text-volume proved to be the third volume of a larger eighteenth-century German work on natural history. I also found the first volume, without plates however. My curiosity was roused when I read a German book auction catalogue offering for sale 35 hand-coloured plates of fishes and reptiles, printed by the Akademische Handlung at Augsburg in 1786 (Anon., 1964). The catalogue mentioned that it had prov- ed impossible to trace the plates to any larger work, but that references to the plates had been found in the catalogue of the British Museum (Anon., 1903-04), Dean (1916) and Keynes (1951).

The difficulties I encountered in my search for the bibliography of these books and plates has led to the present publication.

\section{ACKNOWLEDGEMENTS}

I wish to thank Mrs. Fl. Peeters-Pieters, M.Sc., librarian of the Artis Library Amsterdam, for her interest in the subject and perseverance in tracing the "missing copy" in the Artis Library. I also want to thank my friend Mr. B. Loose, antiquarian, The Hague, for bringing the "Geschenk" to my attention.

I. Geschenk für die Jugend (Gift to young People)

This popular German work on natural history was never completed as far as I can ascertain. The popularity of the works of Buffon, which were also translated into German, may be responsible for this fact.

The information given in the German work is much more thorough and even self-tuition is propagated; the text is, however, not half as readable as Buffon's works. The first volume appeared in 1783 at Augsburg, the second and third volumes were also printed at Augsburg, in 1785 and 1788 respectively and were sent in to the Leipziger Autumn and Spring Fairs (Leipziger Messe) in the years of publication. The format of the three volumes is quarto.

\section{I-A. Bibliography}

Volume I. Angenehmes / und / Lehrreiches / Geschenk / für die / Jugend (half-title, fig 1.) theils 


\section{A N G E N E H M E S}

U N D

\section{LEHRREICHES \\ GESCHENK \\ F Ü R D I E}

\section{J U G E N D.}

Fig. 1. The half-title of volume 1 .

/ zum nuzlichen Zeitvertreib / theils / zu Erweckung eines innerlichen / Antriebs, / nicht nur / die Naturhistorie / zu Erlernen, / sondern auch alsdenn / in reiferen Jahren / durch eigne Untersuchungen / zu helfen, / das dieselbe / je länger je mehr/zu grösserer Vollkommenheit/gebracht, / und / das erlernte auch selbst geprïfte / in eignen und andern Vorfallenheiten / mit Nuzen gebraucht werden kann. / Herausgegeben / von / der gemeinschaftlichen Handlung der kaiserl. privil. franziscischen / Reichs-Akademie F.K.V.W. / in Augsburg. / Mit allergnädigst-kaiserlichen Privilegio. / 1783 (title-page, fig. 2).

The paper cover has a somewhat different title beginning with: Versuch / zu einer allgemeinen / Naturgeschichte / unter dem Titel: / Angenehmes ... Instead of die Naturhistorie it reads Die Naturgeschichte, and instead of Nuzen it uses the different orthography Nutzen (paper cover, fig. 3).

The first volume contains the introduction and deals with the mammals. The introduction is by prefect Herzberg. This volume has 23 plates mainly drawn and engraved by Gottlieb Friedrich Riedel (Dresden 1724-1784 Augsburg, painter on china). Plates I-VII represent examples of the whole animal kingdom (mammals, birds, fishes, amphibians, insects, worms). Plates VIIIXXIII represent the diverse groups of mammals. Plate VIII, however, is only a copy by Riedel of a picture of horses by J. E. Ridinger. The pages of volume I are numbered I-XXXV, 1-100.

Volume II. Erste Fortsetzung / des / angenehmen / und / lehrreichen / Geschenks / für die / Jugend.
/ oder / weitere Versuche / zu / einer allgemeinen / Naturgeschichte, / mit 24 neuen Tabellen / worauf mehr als 753 Vögel in 384 Feldern, / allezeit 16 Felder auf einer Tabelle / befindlich sind. / Herausgegeben /.... . Auf die Leipziger Herbstmesse / 1785 / (title-page, fig. 4.).

The paper cover has a slightly different title beginning with Erste Fortsetzung / des / angenehmen und lehrreichen / Geschenks / für die / Jugend. / Mit 24 Tabellen von Vögeln. / oder / Fortgesetzter Versuch / zu einer allgemeinen / Naturgeschichte. / Theils ..../ 1785 in der Leipziger Herbst-Messe (paper cover, fig. 5).

The second volume deals with the birds and has 24 plates mainly drawn and engraved by Riedel. The numbering of some of the plates is peculiar. Instead of different headings on the 4th, 5th and 6th plates we observe three times the headings of Plate $V$ and number V: Secundae Classis regni animalis: Picas, sive genera, ex ordine Avium Secundo complectens. However, the three plates show different species of woodpeckers and woodland birds. Instead of different headings on the 10th and 11th plates we see twice the heading of Plate $X$ and number $X$ : Secundae Classis, quartum Ordinem, sive Grallas exhibens. However, the two plates show different species of marsh birds. Plates XIX-XXI are copied from the works of Borowsky, Brisson, Buffon, Ebert, Frisch, Leske and Pennant and are not signed by Riedel. The pages of volume II are numbered IXII, 1-33, I-III.

Volume III. Zweite Fortsetzung / des / angeneh- 
T H E I L S

ZUM NUZLICHEN ZEITVERTREIB

T H E I L S

ZU ERWECKUNG EINES INNERLICHEN ANTRIEBS,

$\begin{array}{lllllllllll}N & \text { I } & C & H & T & N & U & R\end{array}$

DIE NATURHISTORIE.

Z U ERLER NEN, SONDERN AUCH ALSDENN

I N R IFEREN JAHRE N

DURCH EIGNE UNTERSUCHUNGEN

Z U HELFEN,

DAS DIESELBE

JE L ÄNGER JE MEHR

ZU GRÖSSERER VOLLKOMMENHEIT GEBRACHT,

$\mathrm{U} N \mathrm{D}$

DAS ERLERNTE AUCH SELBST GEPRÜFTE

IN EIGNEN UND ANDERN VORFALLENHEITEN

MIT NUZEN GEBRAUCHT WERDEN KANN.

$$
\text { Herausgegebon }
$$$$
\mathrm{v} \text { o } \mathrm{n}
$$

der gemeinfchaftlichen Handlung der kaiferl. privil. franziicifchen

REICH S - A K A D E M I E F, K. V. W.

I N A U G B U R G.

Mit allergnädigft - kaiferlichen Privilegio.

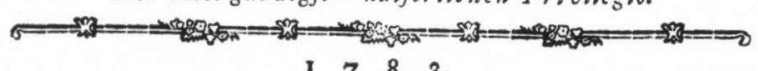

1783 .

Fig. 2 (left), the title-page, and fig. 3 (right), the paper cover of volume $I$.

men / und lehrreichen / Geschenkes / für die / Jugend, / oder / weitere Versuche / zu / einem allgemeinen nicht nur / Les - sondern auch sichtbaren / general Register aus der / Naturgeschichte. / Herausgegeben .... . / Auf die Leipziger Ostermesse / 1788. (title-page, fig. 6). The half-title gives additional information about the number of plates. The halftitle reads: Zweite Fortsetzung / .... / Jugend, / mit 28 neuen Tabellen / worauf 789 Fische, nämlich 430 rayische 271 / blochische und 88 chinesishe in 332 Feldern, deren / allezeit 16 auf einer Tabelle befindlich sind, vorge- / stellet werden.

The cover paper is identical with the title-page. The third volume deals with the fishes engraved by Friedrich Kirschner and has $27+1$ plates. Plates $I-X$ are copies from Ray as given by Willoughby in his Historia Piscium; Plates XIXXIII and XXVII are copies from Bloch's Oeconomische Naturgeschichte der Fische Deutschlands and Plates XXIV-XXVI are copies from

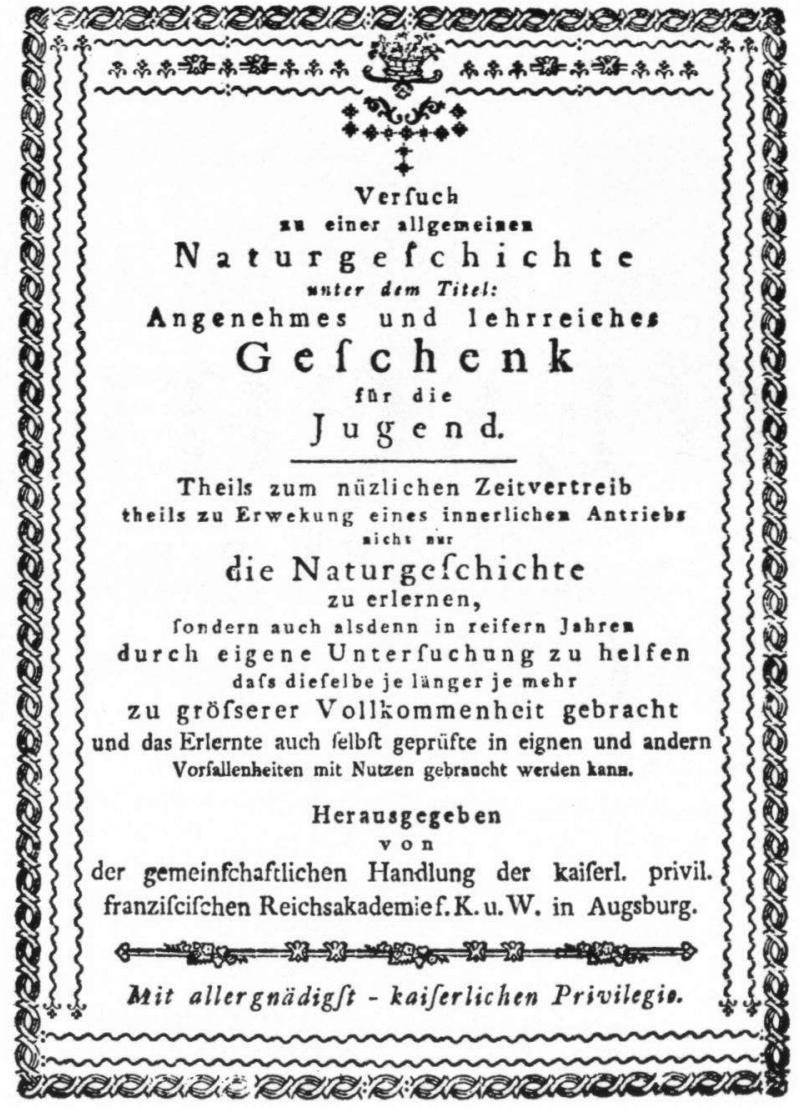

the drawings by Martinet from Sauvigny's Histoire naturelle des Dorades de la Chine. The 28th plate is not numbered and is given by the publisher as an extra plate for collectors. It is a copy by Kirschner of an original coloured drawing by Father Romanus Lazarist from the monastery in Thierhaupten near the river Lech. On it we see a rare fish caught in the Lech by Father Romanus. This plate will receive full attention in the second part of this article. The pages of volume III are numbered I-VI, 1-209, I-XII.

General Index. I was unable to trace any information about a fourth volume and am, therefore, inclined to suppose that there is no fourth volume at all. This volume would possibly have dealt with the amphibians and reptiles, as in $\mathbf{1 7 8 6}$ 8 plates were printed engraved by Kirschner. He copied them from Seba's Thesaurus. In an advertisement in the third volume a General Index is mentioned which was printed on large folio sheets with different sections for the mammals, birds and fishes. The publisher suggested that the section should be bound in the various volumes or that they should be bound together with the 

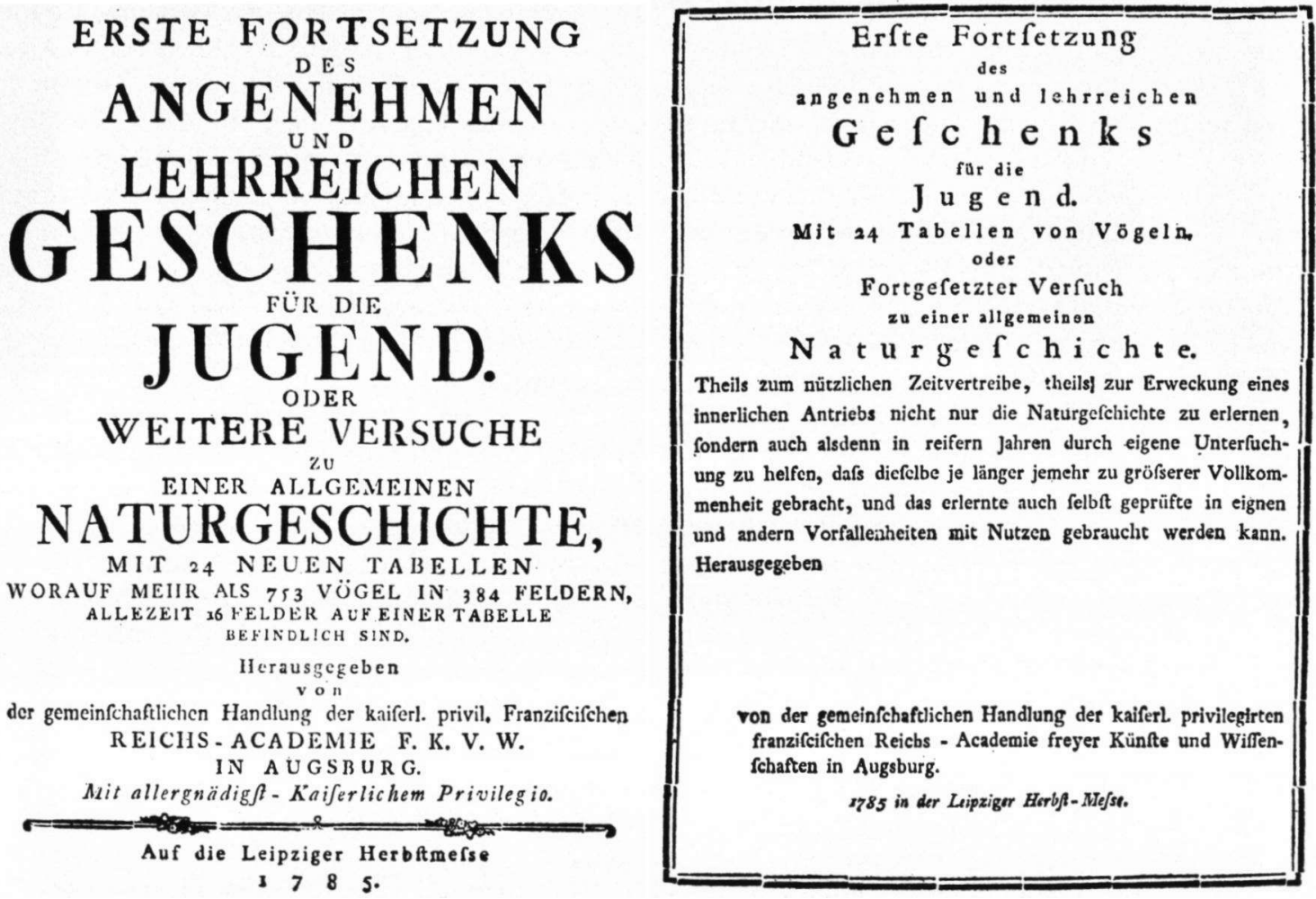

Fig. 4 (left), the title-page, and fig. 5 (right), the paper cover of volume II.

plates on amphibians and reptiles. "In complete volumes bought by the publisher in Augsburg or at the Leipzig Fair this index was already incorporated", as he stated. It is not certain whether this index is the same index in four languages mentioned on the first plate of the third volume.

\section{$I-B$. The plates in general}

The plates were printed on paper of at least two different qualities. The plates of the copy of the Artis Library (former Library of the Royal Zoological Society) are printed on ordinary paper. The plates of the third volume of the copy in my own collection are printed on royal paper. I could trace three different editions of the plates. The plates of the two copies mentioned above and also those which are in the collection of the British Museum (Natural History) are in plain (Anon., 1903-04). In the collection of the Rijksmuseum van Natuurlijke Historie, Leiden, there is a mutilated set of the plates on fishes in sepia. The plates on fishes offered for sale by Hauswedell (Anon., 1964) were handcoloured.
I-C. Review of work of reference in which the "Geschenk" is mentioned.

Dryander (1796) in his catalogue of the library of Joseph Banks in vol. 2 p. 17, Icones Animalium, under the heading Anonymous refers to the first and second volumes, with the plates, under the title: "Angenehmes und lehrreiches geschenk für die jugend". Bank's library presumably lacked the third volume. Carus \& Engelmann (1861) in their Bibliotheca Zoologica, vol. I p. 130 refer to the three volumes of the work under the caption: "Geschenk, Angenehmes und lehrreiches, für die Jugend". However, they do not mention the plates.

Janse (1881), in his catalogue of the library of the (Netherlands) Royal Zoological Society under number 1370 p. 144 Heryberg (Herzberg!) "Angenehmes und lehrreiches Geschenk für die Jugend ...., Augsburg 1783-1788", refers to the three volumes with 75 plates.

The catalogue of the British Museum vol. 1 (1903) p. 72 under the heading Augsburg refers to the $27+1$ plates on fishes and to the 8 plates on amphibians and reptiles by Kirschner. In vol. 
2 (1904) p. 986 under the heading Kirschner (F.) there is also a reference to the same 35 plates $(27+8)$ and to the extra plate of the rare fish captured in the river Lech. There is no mention of the three text-volumes.

Dean (1916) refers four times in his bibliography of fishes to the plates without mentioning the text-volumes. In vol. 1 p. 139 under Bloch he refers to the plates. In vol. 2 p. $634-635$ under Willoughby he refers to Plates $I-X$ and to the "rare fish" plate and gives as year of publication 1789 (sic!). In vol. 3 p. 111 under Kirschner he refers to the 27 plates on fishes, and on p. 331 of the same volume under Willoughby he refers again to Plates $\mathrm{I}-\mathrm{X}$, now however with the correct year of publication, 1786, with a note that this citation is from the catalogue of the British Museum.

Wood (1931) refers in his Introduction p. 538 under the heading Riedel, G. F. and Kirschner, F. to the 85 (sic!) plates. He is, however, uncertain about the year of publication and gives [1750]86.

Keynes (1951) in his Ray bibliography p. 68 -69 mentions the existence of 36 plates in the

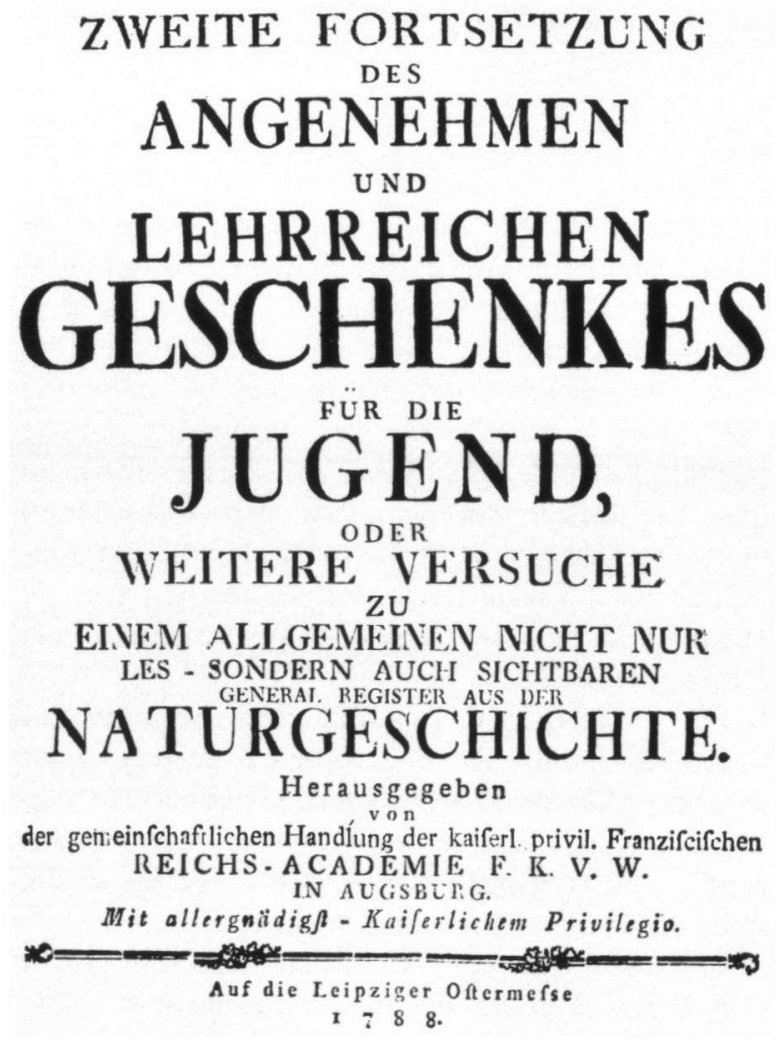

Fig. 6. The title-page of volume III; paper cover and title-page are identical.
Library of the Natural History Museum, London.

In the auction catalogue of Hauswedell (Anon., 1964) there is offered for sale on p. 24 item 125 under the heading Kirschner, F. (G. F. Riedinger, Riedel!) a bound copy of 35 handcoloured plates on fishes and reptiles. The catalogue refers rather funnily to d'Orades (goldfish) as if this is one of the original authors of the plates like Ray and Bloch. It is obvious that the "rare fish" is lacking in the collection they offered for sale.

Nissen (1968) refers in his Zoologische Buchillustration vol. 1 p. 342 under number 3421 to Riedel G. F. and Kirschner, F. and mentions the existence of 83 plates together in four volumes. $\mathrm{He}$ is not certain about the year the printing started as he gives [1780]-1786. There is no mention of the text-volumes. He gives the number and heading of each plate but fails to observe the incorrect numbers of some of the plates in the second volume. He also attributes all the plates to Riedel or Kirschner, yet not all the plates in the second volume are signed by either one or the other of these two engravers. In the card-index system of the University Library of Amsterdam, in which the Artis Library is incorporated, the three volumes of the "Geschenk" are mentioned under number: Artis 204:13. "Versuch zu einer allgemeine Naturgeschichte...". This is the same copy to which Janse (1881) referred under the heading Heryberg (!). In the old hand-written card-index system of the Zoological Society the book was referred to as Herzberg. The mistake was evidently made long ago by some assistant who was unfamiliar with the German way of writing the letter $\mathbf{Z}$.

Summarizing the data given above on the "Geschenk" we see that only four works of reference mention the text-volumes, each in its own way: Anon. (Dryander, 1796); Geschenk (Carus \& Engelmann, 1861); Heryberg (Janse, 1881); Versuch (card-index system University Library Amsterdam, n.d.). According to bibliographic rules nowadays applied in libraries, the only correct reference is that of Carus \& Engelmann. There are six references to the plates alone. The correct number of 83 plates is only given by Nissen $(1968 ; 23,24$, $27,1,8)$. The number of 85 plates given by Wood (1931) must be a mistake.

\section{The rare fish from the river Lech (fig. 7).}

As an addendum to the plates on fish, the publisher of the "Geschenk" printed a copy en- 


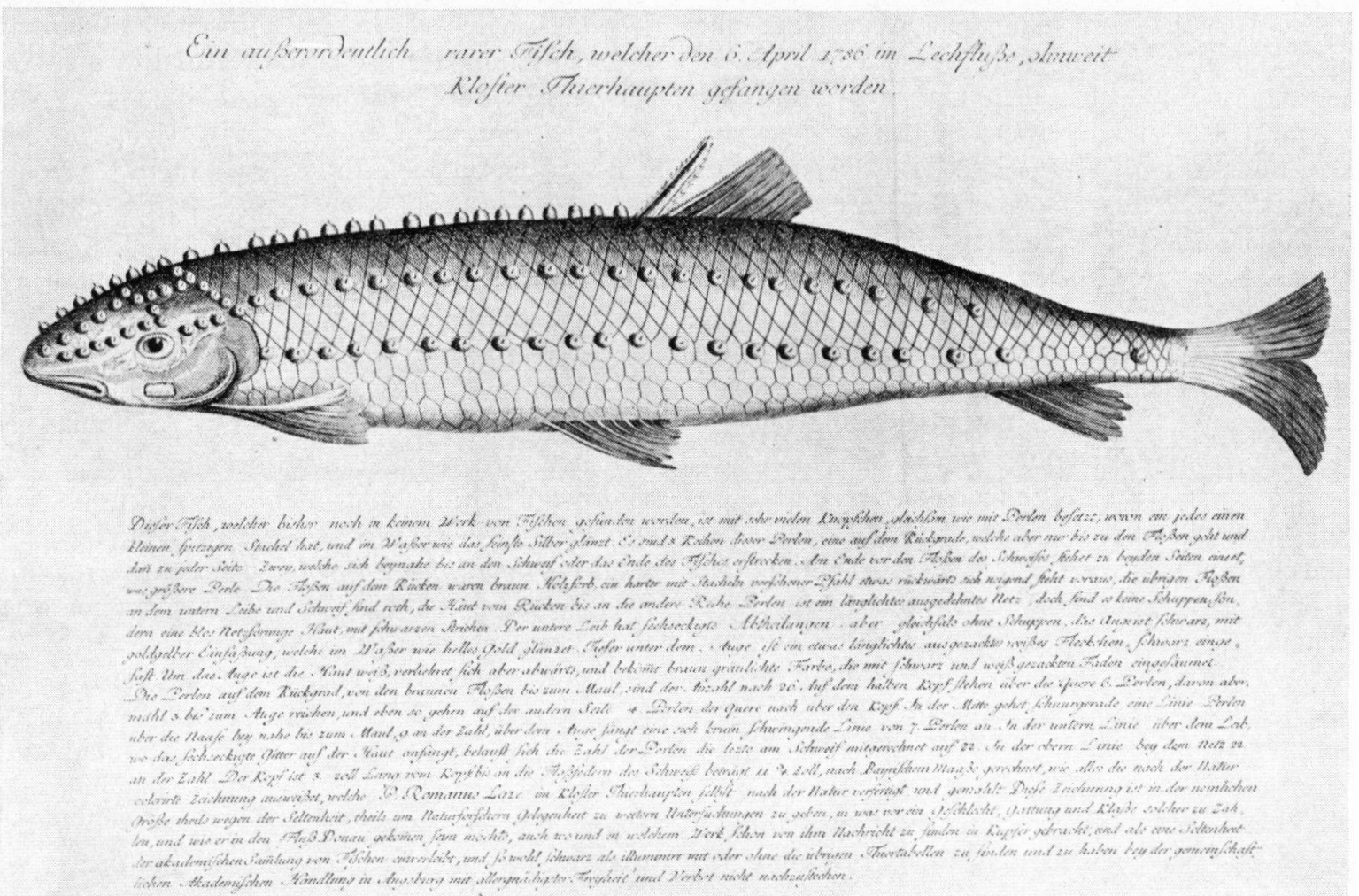

Fig. 7. The rare fish from the river Lech.

graved by Kirschner of an original drawing made by P. Romanus Laze (Father Romanus Lazarist) from the monastery in Thierhaupten near the river Lech in Bavaria, Germany, about $25 \mathrm{~km}$ due north of Augsburg. They sold this plate single or together with the plates of the "Geschenk" in two editions, plain and coloured. The heading to this plate is: "Ein ausserordentlich rarer Fisch, welcher den 6 April 1786 im Lechflusse, ohnweit Kloster Thierhaupten gefangen worden." (An extremely rare fish which was caught in the river Lech, not far from the monastery of Thierhaupten, on the 6th of April 1786). The legend to this plate is:

"Dieser Fisch, welcher bisher noch in keinem Werk von Fischen gefunden worden, ist mit sehr vielen Knöpfchen, gleichsam wie mit Perlen besetzt, wovon ein jedes einen kleinen spitzigen Stachel hat, und im Wasser wie das feinste Silber glänzt. Es sind 5 Reihen dieser Perlen, eine auf dem Rückgrade, welche aber nur bis zu den Flossen geht und dan $\mathrm{zu}$ jeder Seite Zwey, welche sich beynahe bis an den Schweif oder das Ende des Fisches erstrecken. Am Ende vor den Flossen des Schweifes stehet zu beyden Seiten eine etwas grössere Perle. Die
Flossen auf dem Rücken waren braun Holzfarb, ein harter mit Stacheln versehener Pfahl etwas rückwärts sich neigend steht voraus, die übrigen Flossen an dem untern Leibe und Schweif sind roth, die Haut vom Rücken bis an die andere Reihe Perlen ist ein länglichtes ausgedehntes Netz, doch sind es keine Schuppen, sondern eine blos Netzförmige Haut, mit schwarzen Strichen. Der untere Leib hat sechseckigte Abtheilungen, aber gleichfals ohne Schuppen, das Auge ist schwarz, mit goldgelber Einfassung, welche im Wasser wie helles Gold glänzet. Tiefer unter dem Auge ist ein etwas länglichtes ausgezacktes weisses Fleckchen, schwarz eingefast. Um das Auge ist die Haut weiss, verliehret sich aber abwärts, und bekömt braun gräulichte Farbe, die mit schwarz und weiss gezackten Faden eingesäumet. Die Perlen auf dem Rückgrad, von den braunen Flossen bis zum Maul, sind der Anzahl nach 26. Auf dem halben Kopf stehen über die Quere 6 Perlen, davon abermahl 3 bis zum Auge reichen, und eben so gehen auf der andern Seite 4 Perlen der Quere nach über den Kopf. In der Mitte gehet schnurgerade eine Linie Perlen über die Naase bey nahe bis zum 
Maul, 9 an der Zahl, über dem Auge fängt eine sich krum schwingende Linie von 7 Perlen an. In der untern Linie über dem Leib, wo das sechseckigte Gitter auf der Haut anfängt, belauft sich die Zahl der Perlen die letzte am Schweif mitgerechnet auf 22. In der obern Linie bey dem Netz 22 an der Zahl. Der Kopf ist 3 zoll lang; vom Kopfe bis an die Flossfedern des Schweifs beträgt 11 3/4 Zoll, nach Bayrischem Maasse gerechnet, wie alles die nach der Natur colorirte Zeichnung ausweisset, welche P. Romanus Laze im Kloster Thierhaupten selbst nach der Natur verfertigt und gemahlt. Diese Zeichnung ist in der nemlichen Grösse theils wegen der Seltenheit, theils um Naturforschern Gelegenheit zu weitern Untersuchungen zu geben, in was vor ein Geschlecht, Gattung und Klasse solcher zu Zählen, und wie er in den Fluss Donau gekomen seyn möchte, auch wo und in welchem Werk schon vom ihm Nachricht zu finden in Kupfer gebracht, und als eine Seltenheit der akademischen Samlung von Fischen einverleibt, und so wohl schwarz als illuminirt mit oder ohne die übrigen Thiertabellen $\mathrm{zu}$ finden und $\mathrm{zu}$ haben bey der gemeinschaftlichen Akademischen Handlung in Augsburg mit allergnädigster Freyheit und Verbot nicht nachzustechen. F. Kirschner sc.

The biological data may be summarized as follows. The fish of which they could not find any description has a nuptial array. The dorsal fin is wooden brown; there is a dorsal spine; the pectoral-, ventral-, and anal-fin are reddish; the skin is chequered and has black stripes. The eye is black, the iris yellow; around the eye the skin is white, but more lateral greyish brown hemmed with black and white. The length of the head is 3 inches, the total length without the length of the head is $113 / 4$ inches.

The fish is given at natural size, so we are able to derive from the drawing the total length of $41.5 \mathrm{~cm}$ and the greatest depth of body is $6.5 \mathrm{~cm}$.

Owing to the nuptial array, the family to which the fish belongs is identified as a cyprinid. And as this phenomenon is only observed in males, our fish belongs to that sex. The dorsal spine is actually the first spine of the dorsal fin, which was torn presumably during the catching process. If we take into account the body form and colouring, and the geographic region, the river system of the Upper Danube, there are only two species left as possible candidates, Leuciscus virgo Heckel, 1852 (Frauenfisch, Frauennerfling) and Leuciscus meidingeri Heckel, 1852 (Perlfisch, Frauenfisch, Frauennerfling). (See Heckel \& Kner, 1858; Heuschmann, 1957; Bauch, 1963; Ladiges \& Voigt, 1965.) From the German vernacular names we can see that both species are very similar, as identification in the field seems to be rather difficult. Both species spawn in April and May, the males of both species are known for their nuptial array.

This remarkable illustration did not remain unobserved by ichthyologists of the last century, as for instance Schrank and Von Siebold. (Schrank cited in Von Siebold, 1863: 195). Schrank was not able to determine the fish or even its family. However, Von Siebold (195-196) identified the illustrated fish as Leuciscus virgo. Yet, I believe it to be $L$. meidingeri, for the following reasons. (1) $L$. virgo had already been known for centuries in the region of Augsburg. Gessner (1563: 167A) refers to $L$. virgo as Orfus, Orff or Nörffling as being caught around Augsburg and Nuremberg. Aldrovandi (1638: 605) refers also to the Orfo Germanorum, Orff or Norfling inhabiting the waters around Augsburg. (2) The legend of the plate states that no description of the fish represented could be traced. The "Geschenk" volume III: 118 refers to the Orfe (Nerfling, Frauenfisch) and on Plate XVII no. 90 it gives an illustration of this species. (3) Von Siebold refers to the Akademische Handlung in note 1, p. 196, but there is no mention of the "Geschenk". It is, therefore, possible that he was unaware of the fact that the fish plate and the Geschenk belonged together. (4) It is reasonable to assume that an artist, however disputable his artistic value may be, will always try to draw the most outspoken features of his object. Hence we may suppose that the total length and body depth of the fish is reproduced fairly accurately. The best illustrations I could find in the literature of $L$. virgo and $L$. meidingeri are those by Bauch (1963: 108, figs. 47 and 48). The greatest body depth/total length ratio derived from these illustrations is for L. virgo 1:4.4 and for $L$. meidingeri 1:5.8. Heuschmann (1957) even gives for $L$. virgo a ratio of $1: 3.5$. I have already mentioned the total length and body depth of the "rare fish", and this gives us the ratio of 1:6.3. Considering all these points I believe, contrary to Von Siebold, that the "rare fish caught in the river Lech" is Leuciscus meidingeri Heckel, 1852. Bauch (1963) refers to the work of Wagler on $L$. meidingeri and gives data from this work, which enable us to determine our fish as a 5-year-old specimen. 


\section{REFERENCES}

ANON., 1783-88. Angenehmes und Lehrreiches Geschenk für die Jugend ..., 1: $\mathrm{i}-\mathrm{xxxv}, 1-100 ; 2$ : $\mathrm{i}-\mathrm{xii}$, 1-33, i-iii; 3 : i-iv, 1-209, i-xii; 83 pls. (Gem. Handl. d. Kaiserl. privil. franziscischen Reichs-Akademie F.K.V.W., Augsburg).

ANON., 1903-04. Catalogue of the books, manuscripts, maps and drawings in the British Museum (Natural History), 1 (= A-D): 72 (London, 1903); 2 (= E-K): 986 (London, 1904).

-, 1964. Fischbücher aus fünf Jahrhunderten - Antiquariatskatalog, 196 - Auktion 130 : 1-32. (Dr. E. Hauswedell, Hamburg).

Aldrovand, U., 1638. De Piscibus libri V et de Cetis liber I: $1-732$. (N. Thebaldini, Bononiae).

BauCH, G., 1963. Die Einheimischen Süsswasserfische, 4e Aufl.: 1-198. (Neuman \& Radebeul, Berlin).

Carus, J. V. \& W. EngelmanN, 1861. Bibliotheca Zoologica - Verzeichniss der Schriften über Zoologie, welche in den periodischen Werken enthalten und vom Jahre 1846-1860 selbständig erschienen sind, mit Einschluss der allgemein-naturgeschichtlichen, periodischen und palaeontologischen Schriften, 1: 130. (W. Engelmann, Leipzig).

Dean, B., 1916. A bibliography of fishes, 1: 139; 2: 634; 3: 111, 331. (Amer. Mus. Nat. Hist., New York).

DRYANDER, J., 1796. Catalogus bibliotheca historico-naturalis Josephi Banks, 2: 17. (Zoologi). (Bulmer, Londini).
Gessner, C., 1563. Fischbuch: 1-404, (Froschauer, Zürich).

HeCkel, J. \& R. KneR, 1858. Die Süsswasserfische der Ostreichischen Monarchie mit Rücksicht auf die Angränzenden Länder: 1-388 (W. Engelmann, Leipzig).

HeuschmanN, O., 1957. Die Weissfische (Cyprinidae). In: Handb. Binnenfischerei Mitteleuropas, 3 B (18): 23-199. (R. Demoll \& H. N. Maier, Stuttgart).

JANSE, G., 1881. Catalogus der bibliotheek van het Koninklijk Zoölogisch Genootschap Natura Artis Magistra te Amsterdam: 144, 506 (Scheltema \& Holkema, Amsterdam).

KEYNES, G., 1951. John Ray, a bibliography: 1-163 (Faber \& Faber, London).

Ladiges, W. \& D. Voigt, 1965. Die Süsswasserfische Europa's bis zum Ural und Kaspischen Meer: 1250. (Paul Parey, Hamburg).

Nissen, C., 1966-69. Die zoologische Buchillustration. Ihre Bibliographie und Geschichte, 1. Bibliographie, 5 (: 321-400, Mai 1968): 342. (Anton Hiersemann, Stuttgart).

Siebold, G. Th. E. von, 1863. Die Süsswasserfische von Mitteleuropa: 1-430. (W. Engelmann, Leipzig).

WooD, C. A., 1931. An introduction to the literature of vertebrate zoology: 1-643. (Oxford Univ. Press. London). 